\title{
PENERAPAN METODE BERMAIN PERAN KONSEP DASAR PKN MI/SD UNTUK MENINGKATKAN MOTIVASI BELAJAR MAHASISWA PGMI UNISKA MAB BANJARMASIN
}

\author{
Oleh: \\ Desy Anindia Rosyida \\ Jumiati \\ Dosen, UNISKA MAB Banjarmasin, Kalimantan Selatan Indonesia \\ Email: desyanindia18@gmail.com, jumiati,jumi88@gmail.com
}

\begin{abstract}
Abstrak
Pendidikan kewarganegaraan merupakan salah satu mata kuliah yang diajarkan di universitas. Mata kuliah tersebut juga termasuk dalam Mata kuliah gabungan universitas (MGU). Karena esensi yang begitu penting, PKn tidak hanya mengajarkan materi kepada mahasiswa saja. Salah satu pengembangan mata kuliah Pendidikan Kewarganegaraan adalah Konsep dasar Pendidikan Kewarganegaraan (PKn) MI/SD. Materi sistem demokrasi adalah salah satu materi yang sangat dekat dengan mahasiswa dan sering diaplikasi dalam kehidupan sehari-hari. Pembelajaran materi sistem demokrasi, jika hanya dijelaskan dengan metode ceramah terkadang kurang efektif dan efisien. Pembelajaran dengan menggunakan metode bermain peran (role play), lebih efektif, menyenangkan dan mudah dipahami oleh mahasiswa daripada hanya dengan menggunakan metode ceramah dan diskusi saja. Mereka lebih antusias dan berperan aktif dalam kegiatan belajar mengajar. Karena metode bermain peran (role play), meliputi aspek kognitif, psikomotorik dan afektif. Penelitian menggunakan metode deskriptif kualitatif dan kuantitatif (dengan angket). Dari analisis data angket yang telah disebarkan kepada 21 responden dengan 7 item pernyataan diperoleh nilai dengan rata-rata 30,05 , maka penerapan metode
\end{abstract}


Desy Anindia Rosyida dan Jumiati: Penerapan Metode Bermain Peran Konsep Dasar PKn MI/SD untuk Meningkatkan Motivasi Belajar Mahasiswa PGMI UNISKA MAB Banjarmasin

bermain peran (role play) Konsep Dasar PKn MI/SD materi Sistem Demokrasi berpengaruh pada motivasi belajar mahasiswa PGMI UNISKA MAB Banjarmasin.

Kata Kunci: Metode Bermain Peran, Konsep Dasar PKn MI/SD, Motivasi Belajar

\section{A. Pendahuluan}

Pendidikan kewarganegaraan merupakan salah satu mata kuliah yang diajarkan di universitas. Mata kuliah tersebut juga termasuk dalam Mata kuliah gabungan universitas (MGU). Karena esensi yang begitu penting, PKn tidak hanya mengajarkan materi kepada mahasiswa saja. Namun juga mengajarkan karakter yang baik kepada peserta didik. Kandungan dalam sila-sila pancasila meliputi seluruh kehidupan masyarakat Indonesia secara keseluruhan.

Salah satu pengembangan mata kuliah Pendidikan Kewarganegaraan adalah Konsep dasar Pendidikan Kewarganegaraan (PKn) MI/SD. Konsep dasar Pendidikan Kewarganegaraan (PKn) MI/SD adalah salah satu mata kuliah kePGMI-an yang ada di Universitas Islam Kalimantan Muhammad Arsyad AlBanjari Banjarmasin. Materi Konsep dasar PKn MI/SD meliputi:

a. Hakikat Pendidikan Kewarganegaraan

b. Nilai, norma dan moral, hukum dan perundang-undangan

c. Pancasila sebagai ideologi Negara

d. Negara dan warga Negara

e. Hak Asasi Manusia (HAM) serta hak dan kewajiban Warga Negara Indonesia (WNI)

f. Sistem politik dan kekuasaan

g. Sistem konstitusional

h. Sistem Pemerintahan

i. Sistem Demokrasi

j. Persatuan dan Kesatuan Bangsa

Materi sistem demokrasi adalah salah satu materi yang sangat dekat dengan mahasiswa dan sering diaplikasi dalam kehidupan sehari-hari. 
Desy Anindia Rosyida dan Jumiati: Penerapan Metode Bermain Peran Konsep Dasar PKn MI/SD untuk Meningkatkan Motivasi Belajar Mahasiswa PGMI UNISKA MAB Banjarmasin

Pembelajaran materi sistem demokrasi, jika hanya dijelaskan dengan metode ceramah terkadang kurang efektif dan efisien. Sehingga diperlukan terobosan baru dalam mempelajari materi tersebut, yaitu dengan menggunakan metode bermain peran (role play).

Pembelajaran dosen dan mahasiswa sering dihadapkan pada berbagai masalah, baik yang berkaitan dengan mata pelajaran maupun yang menyangkut hubungan sosial. Pemecahan masalah pembelajaran dapat dilakukan melalui berbagai cara, melalui diskusi kelas, tanya jawab antara guru dan peserta didik, penemuan dan inkuiri. Dosen yang kreatif senantiasa mencari pendekatan baru dalam memecahkan masalah, tidak terpaku pada cara tertentu yang monoton, melainkan memilih variasi lain yang sesuai. Bermain peran merupakan salah satu alternative yang dapat ditempuh. Hasil penelitian dan percobaan yang dilakukan oleh para ahli menunjukkan bahwa bermain peran merupakan salah satu model yang dapat digunakan secara efektif dalam pembelajaran. Hal ini karena, bermain peran diarahkan pada pemecahan masalah yang menyangkut hubungan antar manusia, terutama yang menyangkut kehidupan peserta didik. Manusia merupakan makhluk sosial dan individual, yang dalam hidupnya senantiasa berhadapan dengan manusia lain atau situasi di sekelilingnya. Sebagai individu manusia memiliki pola yang unik dalam berhubungan dengan manusia lain. Ia memiliki rasa senang, tidak senang, percaya, curiga, dan ragu terhadap orang lain. Namun perasaan tersebut diarahkan juga pada dirinya. Perasaan dan sikap terhadap orang lain dan dirinya itu mempengaruhi pola respon individu terhadap individu lain atau situasi di luar dirinya. Karena senang dan penasaran ia cenderung mendekat. Karena tidak senang dan curiga ia cenderung menjauh manifestasi tersebut disebut peran.

Mahasiswa merupakan peserta didik yang diharapkan memiliki tingkat intelektual yang lebih dibandingkan dengan yang lain. Karena diajarkan berbagai mata kuliah sebagai bekal terjun langsung pada lingkungan kerja maupun pada masyarakat. Mahasiswa jurusan Pendidikan Guru Madrasah 
Desy Anindia Rosyida dan Jumiati: Penerapan Metode Bermain Peran Konsep Dasar PKn MI/SD untuk Meningkatkan Motivasi Belajar Mahasiswa PGMI UNISKA MAB Banjarmasin

Ibtidaiyah (PGMI) mendapatkan berbagai mata kuliah umum dan khusus. Mereka diajari bagaimana cara menyampaikan materi dengan benar dan tepat kepada anak didik yaitu anak usia MI/SD, diajari cara membuat perangkat pembelajaran, serta praktik langsung ke lapangan. Sudah sepatutnya, para calon guru juga memahami dan bisa mempraktikkan metode pembelajaran sebelum mereka terjun langsung ke MI/SD.

Karakter belajar antara mahasiswa satu dengan yang lainnya berbeda. Mereka berasal dari berbagai latar belakang pendidikan yang berbeda pula. Pada kampus Uniska Muhammad Arsyad Al-Banjary Banjarmasin, khususnya jurusan PGMI memiliki lima kelas yaitu dua kelas di Banjarmasin, dua kelas di Banjarbaru, dan satu kelas di Kandangan. Namun, di sini peneliti meneliti dua kelas di Banjarmasin dan dua kelas di Banjarbaru.

\section{B. Metode Penelitian}

Penelitian menggunakan penelitian deskriptif kualitatif dan kuantitatif. Penelitian deskriptif kualitatif adalah prosedur penelitian yang menghasilkan data deskriptif berupa kata-kata tertulis atau lisan dari orang-orang dan perilaku yang dapat diamati dari sumber data. Pendekatan kualitatif deskriptif adalah penelitian yang dimaksudkan untuk memahami fenomena tentang apa yang dialami oleh subjek penelitian; misalnya perilaku, persepsi, tindakan dan lainlain, secara holistik dan dengan cara deskripsi dalam bentuk kata-kata dan bahasa, dalam suatu konteks khusus yang alamiah dan dengan memanfaatkan berbagai metode ilmiah. ${ }^{1}$ Penelitian kuantitatif yang digunakan dengan perhitungan tingkat motivasi belajar mahasiswa melalui angket.

Pelaksanaan penelitian dan kajiannya didasarkan pada proses pencarian data secara lengkap. Selanjutnya data tersebut disajikan secara deskriptif dalam bentuk kata-kata untuk memperoleh keutuhan deskripsi atau gambaran tentang

${ }^{1}$ Lexy J. Moeleong, 2005, Metode Penelitian Kualitatif, Bandung : Remaja Rosdakarya, h. 6.

Al-Madrasah: Jurnal Ilmiah Pendidikan Madrasah Ibtidaiyah Vol. 3, No. 2, Januari-Juni 2019 
Desy Anindia Rosyida dan Jumiati: Penerapan Metode Bermain Peran Konsep Dasar PKn MI/SD untuk Meningkatkan Motivasi Belajar Mahasiswa PGMI UNISKA MAB Banjarmasin

penerapan metode bermain peran (Role Play) Konsep Dasar PKn MI/SD materi sistem demokrasi untuk meningkatkan motivasi belajar mahasiswa PGMI UNISKA MAB Banjarmasin. Peneliti ingin mendeskripsikan cara penerapan metode bermain peran (Role Play) Konsep Dasar PKn MI/SD materi Sistem Demokrasi pada mahasiswa PGMI UNISKA MAB Banjarmasin dan ingin mengetahui tingkat motivasi belajar mahasiswa PGMI UNISKA MAB Banjarmasin dengan penerapan metode bermain peran (Role Play) Konsep Dasar PKn MI/SD materi Sistem Demokrasi.

Penelitian ini akan dilakukan di kampus UNISKA MAB Banjarmasin Jl. Kayu Tangi No. 2 Banjarmasin dan kampus UNISKA MAB Banjarbaru. Populasi dalam penelitian ini adalah mahasiswa PGMI UNISKA MAB kelas A dan B Banjarbaru serta mahasiswa PGMI UNISKA MAB kelas A dan B. Adapun jumlah populasi pada mahasiswa PGMI Banjarbaru adalah 7 orang, dan jumlah populasi pada mahasiswa Banjarmasin adalah 14 orang. Penelitian inii menggunakan seluruh populasi sebagai sampel dikarenakan jumlah sampel kurang dari 100. sehingga penelitian ini disebut penelitian populasi.

Sumber data dalam sebuah penelitian adalah subjek dari mana data tersebut diperoleh. Jika dalam pengumpulan datanya peneliti menggunakan tekhnik observasi, maka sumber datanya bisa berupa benda, gerak, atau proses sesuatu. Apabila peneliti menggunakan wawancara dalam pengumpulan datanya, maka sumber datanya disebut informan. Apabila peneliti menggunakan dokumentasi, maka dokumen atau catatan tersebut yang menjadi sumber data. ${ }^{2}$

Sumber Data Informasi atau informan dari data ini adalah pihak-pihak yang termasuk dalam Jurusan PGMI UNISKA MAB Banjarmasin, yaitu Ketua Jurusan PGMI, Sekretaris PGMI, dosen-dosen PGMI, serta mahasiswa PGMI UNISKA MAB Banjarmasin dan Banjarbaru. Peneliti melakukan pengumpulan

${ }^{2}$ Suharsimi Arikunto, 2002, Prosedur Penelitian, Jakarta : Rineka Cipta, h. 107

Al-Madrasah: Jurnal Ilmiah Pendidikan Madrasah Ibtidaiyah Vol. 3, No. 2, Januari-Juni 2019 
Desy Anindia Rosyida dan Jumiati: Penerapan Metode Bermain Peran Konsep Dasar PKn MI/SD untuk Meningkatkan Motivasi Belajar Mahasiswa PGMI UNISKA MAB Banjarmasin

data melalui wawancara semua pihak terkait, serta mahasiswa PGMI UNISKA MAB; dokumentasi; dan observasi.

Menurut Lofland, yang dikutip oleh Moleong, sumber data penelitian yang kualitatif adalah kata-kata atau tindakan, selebihnya adalah data tambahan, seperti dokumen, dan lain-lain. Berkaitan dengan hal itu, pada bagian ini, jenis datanya terbagi menjadi kata-kata dan tindakan, sumber data tertulis, foto.

a. Kata-kata dan tindakan.

Kata-kata dan tindakan orang yang diamati atau diwawancarai merupakan sumber data utama, atau disebut juga data primer, yaitu data langsung dikumpulkan oleh peneliti (atau petugas-petugasnya) dari sumber pertamanya. Sedangkan selebihnya adalah data skunder. ${ }^{3}$

b. Sumber tulis

Sumber tertulis dapat dibagi atas sumber buku dan majalah ilmiah, sumber arsip, dokumen pribadi dan dokumen resmi. ${ }^{4}$

c. Foto

Foto sudah banyak dipakai sebagai alat untuk keperluan penelitian kualitatif karena dapat dipakai dalam berbagai keperluan. Foto menghasilkan data deskriptif yang cukup berharga dan sering digunakan untuk menelaah segi-segi subjektif dan hasilnya sering dianalisis secara indukatif. $5^{5}$

Dalam pengumpulan data, peneliti menghimpun data secara empiris. Dari data tersebut dimaksudkan untuk memahami ragam kegiatan yang dikembangkan menjadi suatu pola temuan peneliti, pola temuan tersebut selanjutnya diverifikasikan dengan menguji kebenaranya bertolak pada data baru yang spesifik Teknik pengumpulan data yang digunakan dalam penelitian ini adalah:

${ }^{3}$ Sumardi Suryabrata, 1998, Metodologi Penelitian, Jakarta : Raja Grafindo Persada

${ }^{4}$ Lexy J. Moeleong, Op. Cit, h. 159.

${ }^{5}$ Ibid, h. 169.

Al-Madrasah: Jurnal Ilmiah Pendidikan Madrasah Ibtidaiyah Vol. 3, No. 2, Januari-Juni 2019 
Desy Anindia Rosyida dan Jumiati: Penerapan Metode Bermain Peran Konsep Dasar PKn MI/SD untuk Meningkatkan Motivasi Belajar Mahasiswa PGMI UNISKA MAB Banjarmasin

\section{a. Metode Observasi}

Menurut Suharsimi Arikunto yaitu pengamatan yang meliputi kegiatan pemusatan perhatian terhadap sesuatu objek dengan menggunakan pencatatan. ${ }^{6}$ Metode observasi adalah metode pengumpulan data dengan mengadakan pengamatan dengan pencatatan secara sistematis terhadap kenyataan yang diselidiki. Dalam hal ini peneliti menggunakan observasi partisipan yaitu tekhnik pengumpulan data dimana peneliti mengadakan pengamatan secara langsung terhadap gejala-gejala subjek yang diselidiki.

\section{b. Metode Wawancara}

Metode interview atau metode Wawancara adalah sebuah dialog yang oleh pewawancara untuk memperoleh informasi dari terwawancara. ${ }^{7}$ Lexy J. Moleong, menjelaskan wawancara merupakan percakapanpercakapan dengan maksud tertentu, percakapan ini dilaksanakan oleh dua pihak yaitu pewawancara yang mengajukan pertanyaan dengan yang diwawancarai memberikan jawaban atas pertanyaan itu. ${ }^{8}$ Wawancara ini dilakukan untuk memperoleh data tentang masalah-masalah yang berkaitan dengan penerapan metode bermain peran (role play) Konsep Dasar PKn MI/SD materi Sistem Demokrasi pada mahasiswa Banjarmasin dan Banjarbaru. Adapun sumber informasi (informan) adalah kepala sekolah, semua guru (khususnya guru agama), dan siswa.

\section{c. Metode Dokumentasi}

Suharsimi Arikunto, menjelaskan bahwa metode dokumentasi adalah metode mencari data mengenai hal-hal yang variabelnya berupa catatan, transip, buku, surat kabar, majalah, notulen rapat, agenda dan sebagainya. Metode ini digunakan untuk mendokumentasikan tentang proses pembelajaran di kelas serta dapat membedakan antara yang belum

${ }^{6}$ Suharsimi Ari Kunto, 1993, Prosedur Penelitian Suatu Pendekatan Praktis, Jakarta : Bina Aksara, h. 38.

${ }^{7}$ Ibid, h. 26.

${ }^{8}$ Lexy J Moloeng. Op. Cit. h. 135.

Al-Madrasah: Jurnal Ilmiah Pendidikan Madrasah Ibtidaiyah Vol. 3, No. 2, Januari-Juni 2019 
Desy Anindia Rosyida dan Jumiati: Penerapan Metode Bermain Peran Konsep Dasar PKn MI/SD untuk Meningkatkan Motivasi Belajar Mahasiswa PGMI UNISKA MAB Banjarmasin

menggunakan metode bermain peran dan yang sudah menggunakan metode bermain peran.

\section{Teknik Analisis Data}

Penulis menggunakan metode deskriptif kualitatif yaitu analisis data dilakukan dengan menata dan menelah secara sistematis semua data yang diperoleh. Penelitian deskriptif adalah penelitian yang menggunakan suatu peristiwa, gejala, kejadian, yang terjadi pada saat sekarang, artinya penelitian deskriptif adalah mengambil masalah atau memusatkan perhatian kepada masalah-masalah aktual sebagaimana adanya pada saat penelitian dilaksanakan. Penelitian yang semacam ini disebut dengan penelitian yang berusaha mencari informasi aktual yang mendetail yang menggambarkan identifikasi masalah atau mendapatkan justifikasi keadaan dan praktek yang sedang berlangsung.

\section{Pengecekan Keabsahan Data}

Selain menganalisis data, peneliti juga harus menguji keabsahan data agar memperoleh data yang valid. Untuk menetapkan keabsahan data tersebut diperlukan tekhnik pemeriksaan. Adapun tekhnik yang digunakan dalam pemeriksaan keabsahan data adalah sebagai berikut:

a. Observasi yang diperdalam

Dalam penelitian ini, memperdalam observasi dimaksudkan untuk menemukan ciri-ciri dan unsur-unsur dalam situasi yang sangat relevan dengan persoalan atau isu yang sedang dicari dan kemudian memusatkan diri pada hal-hal tersebut secara rinci. Hal ini berarti peneliti hendaknya mengadakan pengamatan dengan teliti dan rinci secara berkesinambungan terhadap faktor-faktor yang menonjol. Kemudian menelaah kembali secara rinci sampai pada suatu titik sehingga pada pemeriksaan tahap awal tampak salah satu atau seluruh factor yang ditelaah sudah dipahami dengan cara yang biasa. Untuk keperluan itu teknik ini menuntut agar peneliti mampu menguraikan 
Desy Anindia Rosyida dan Jumiati: Penerapan Metode Bermain Peran Konsep Dasar PKn MI/SD untuk Meningkatkan Motivasi Belajar Mahasiswa PGMI UNISKA MAB Banjarmasin

secara rinci bagaimana proses penemuan secara tentatif dan penelaahan secara terperinci tersebut dapat dilakukan.

b. Trianggulasi

Trianggulasi adalah teknik pemeriksaan keabsahan data yang memanfaatkan sesuatu yang lain, diluar data itu untuk keperluan pengecekan atau sebagai pembanding data lain itu, tekhniknya dengan pemeriksaan sumber data lainnya.

Trianggulasi yang digunakan adalah : 1) Trianggulasi data, yaitu dengan cara membandingkan data hasil wawancara. Hal yang diperiksa dengan teknik triangulasi berupa kegiatan keagamaan yang dilaksanakan madrasah dengan pendidikan karakter terhadap siswa, dan dengan perbandingan itu diharapkan dapat menyatukan persepsi atas data yang diperoleh, 2) Trianggulasi metode, dilakukan dengan cara : a) Mengecek derajat kepercayaan temuan penelitian dengan beberapa teknik pengumpulan data, dan b) Mengecek derajat kepercayaan beberapa sumber data dengan teknik yang sama. Dua jenis triangulasi metode ini dimaksudkan untuk memverifikasi dan menvalidasi analisis data kualitatif, 3) Trianggulasi peneliti lain, yaitu dengan membandingkan beberapa hasil penelitian yang dilakukan di kampus UNISKA MAB Banjarmasin dan Banjarbaru.

\section{Hasil dan Pembahasan}

\section{a. Penerapan metode bermain peran (Role Play) Konsep Dasar PKn MI/SD materi Sistem Demokrasi pada mahasiswa PGMI UNISKA MAB Banjarmasin}

Pendidikan Kewarganegaraan (PKn) adalah salah satu mata pelajaran yang dipelajari dari tingkat sekolah dasar sampai perguruan tinggi. Materi yang diajarkan pada mata pelajaran PKn cenderung sama dari tingkat dasar sampai perguruan tinggi. Akan tetapi ada yang membedakan yaitu tingkat kerumitan 
Desy Anindia Rosyida dan Jumiati: Penerapan Metode Bermain Peran Konsep Dasar PKn MI/SD untuk Meningkatkan Motivasi Belajar Mahasiswa PGMI UNISKA MAB Banjarmasin

materi dan cara guru maupun dosen dalam menyampaikan sebuah materi. Pembelajaran PKn cenderung membosankan bagi sebagian peserta didik. Sedangkan pembelajaran zaman sekarang adalah yang berpusat pada peserta didik (student center), berbeda dengan zaman dahulu yang hanya berpusat pada guru (teacher center). Oleh karena itu, pendidik harus lebih kreatif dalam melaksanakan pembelajaran, terutama pembelajaran PKn. Pembelajaran tidak hanya dilakukan di dalam kelas dengan duduk diam mendengarkan. Tetapi, bisa dengan inovasi pembelajaran yang menyenangkan salah satunya dengan menggunakan metode bermain peran (role play). Metode pembelajaran ini bisa digunakan untuk jenjang pendidikan dasar sampai perguruan tinggi, dengan meliputi aspek kognitif, psikomotorik, dan afektif.

Materi-materi yang dipelajari pada PKn mayoritas membaca dan mempresentasikan di depan kelas, dan hal tersebut sangat membosankan. Mahasiswa, khusunya mahasiswa PGMI harus mengetahui metode-metode pembelajaran menarik untuk pembelajaran setiap pelajaran, agar pembelajaran hidup dan tidak monoton. Oleh karena itu, peran aktif dosen dalam memberikan materi kepada mahasiswa PGMI, yaitu mahasiswa yang diharapkan sebagai calon pendidik di pendidikan dasar, harus mempunyai kreatifitas dalam menyampaikan sebuah materi. Pembelajaran yang berhasil adalah pembelajaran yang menyenangkan, berkesan dan dapat merubah cara pandang.

Salah satu materi yang diajarkan adalah materi Sistem Demokrasi. Demokrasi adalah kata yang sering kita dengar di masyarakat. Ketika hanya membaca sebuah materi saja, peserta didik bisa lupa. Tetapi jika terlebih dahulu membaca, kemudian dipraktikkan akan menambah ketajaman ingatan peserta didik, yaitu dengan menggunakan metode bermain peran (role play) materi sistem demokrasi.

Materi tersebut peneliti pilih, karena yang paling banyak dilihat dan dialami langsung oleh masyarakat, terutama bagi peserta didik. Diharapkan mereka akan memiliki pengetahuan lebih ketika sudah melaksanakan 
Desy Anindia Rosyida dan Jumiati: Penerapan Metode Bermain Peran Konsep Dasar PKn MI/SD untuk Meningkatkan Motivasi Belajar Mahasiswa PGMI UNISKA MAB Banjarmasin

pembelajaran Konsep Dasar PKn MI/SD dengan menggunakan metode bermain peran (role play) materi Sistem Demokrasi.

Tahap-tahap pelaksanaan metode bermain peran (role play) materi Sistem Demokrasi pada mahasiswa PGMI UNISKA MAB Banjarmasin, antara lain sebagai berikut:

1. Dosen meminta mahasiswa untuk mempelajari tentang sistem demokrasi secara lengkap (pengertian, macam-macam, sistem demokrasi di Indonesia dan pelaksanaannya).

2. Mahasiswa berdiskusi secara berkelompok tentang apa yang telah dipelajari sebelumnya dan mempresentasikan di depan kelas.

3. Dosen mendampingin mahasiswa dalam berdiskusi dan presentasi.

4. Pada pertemuan berikutnya, mulai penerapan metode bermain peran (role play) materi Sistem Demokrasi, yaitu dengan menggunakan simulasi pemilu.

5. Mahasiswa membagi peran pada setiap bagian-bagian yang bertugas untuk simulasi pemilu.

6. Mahasiswa menyiapkan terlebih dahulu peralatan yang diperlukan untuk simulasi, antara lain kardus, kertas pemilihan, alat coblos, alat tulis, tinta, papan penghitungan suara, meja dan kursi. Peralatan menggunakan alatalat yang tersedia dan mudah dicari.

7. Ketika semua peralatan sudah siap, maka pelaksanaan simulasi pemilu dilaksanakan.

8. Pelaksanaan simulasi pemilu dilaksanakan dari awal sampai akhir, layaknya pemilu yang dilakukan oleh pemerintah.

b. Mengetahui tingkat motivasi belajar mahasiswa PGMI UNISKA MAB Banjarmasin dengan penerapan metode bermain peran (Role Play) Konsep Dasar PKn MI/SD materi Sistem Demokrasi.

Peneliti menggunakan angket untuk mengetahui tingkat motivasi belajar mahasiswa UNISKA MAB Banjarmasin pada mata kuliah Konsep Dasar PKn 
Desy Anindia Rosyida dan Jumiati: Penerapan Metode Bermain Peran Konsep Dasar PKn MI/SD untuk Meningkatkan Motivasi Belajar Mahasiswa PGMI UNISKA MAB Banjarmasin

MI/SD materi sistem demokrasi dengan menggunakan metode bermain peran (role play). Ada 4 jenis motivasi belajar, yaitu: perhatian, kesesuaian, percaya diri, dan kepuasan.

Adapun angket tersebut adalah sebagai berikut:

Tabel 1. Angket motivasi belajar terhadap metode bermain peran (role play)

\begin{tabular}{|c|c|c|c|c|c|c|}
\hline No & Pernyataan & STS & TS & $\mathbf{K S}$ & $\mathbf{S}$ & SS \\
\hline 1 & $\begin{array}{l}\text { Saya merasa pembelajaran } \\
\text { Konsep Dasar PKn MI/SD } \\
\text { lebih mudah diterima dengan } \\
\text { penerapan langsung }\end{array}$ & & & & & \\
\hline 2 & $\begin{array}{l}\text { Saya memahami materi sistem } \\
\text { demokrasi dengan metode } \\
\text { bermain peran (role play) }\end{array}$ & & & & & \\
\hline 3 & $\begin{array}{l}\text { Saya menyukai penerapan } \\
\text { metode bermain (role play) } \\
\text { pada mata kuliah Konsep } \\
\text { Dasar PKn MI/SD }\end{array}$ & & & & & \\
\hline 4 & $\begin{array}{l}\text { Saya lebih konsentrasi saat } \\
\text { mengikuti kegiatan belajar } \\
\text { mengajar Konsep Dasar PKn } \\
\text { MI/SD }\end{array}$ & & & & & \\
\hline 5 & \begin{tabular}{llll} 
Saya & rajin & \multicolumn{2}{c}{ mendiskusikan } \\
materi & $\mathrm{PKn}$ & dengan teman- \\
teman & & & \\
\end{tabular} & & & & & \\
\hline 6 & $\begin{array}{l}\text { Saya semangat mengikuti } \\
\text { kuliah Konsep Dasar PKn } \\
\text { MI/SD dengan menerapkan } \\
\text { metode bermain peran (role } \\
\text { play) karena menyenangkan } \\
\text { dan mudah diterima }\end{array}$ & & & & & \\
\hline 7 & $\begin{array}{l}\text { Saya selalu mempersiapkan } \\
\text { materi Konsep Dasar PKn } \\
\text { MI/SD ketika akan memulai } \\
\text { perkuliahan }\end{array}$ & & & & & \\
\hline
\end{tabular}

Keterangan:

- STS = Sangat Tidak Setuju (nilai 1)

- $\mathrm{TS}=$ Tidak Setuju (nilai 2)

- $\mathrm{KS}=$ Kurang Setuju (nilai 3)

Al-Madrasah: Jurnal Ilmiah Pendidikan Madrasah Ibtidaiyah Vol. 3, No. 2, Januari-Juni 2019 
Desy Anindia Rosyida dan Jumiati: Penerapan Metode Bermain Peran Konsep Dasar PKn MI/SD untuk Meningkatkan Motivasi Belajar Mahasiswa PGMI UNISKA MAB Banjarmasin

- $\mathrm{S} \quad=$ Setuju (nilai 4)

- $\mathrm{SS} \quad=$ Sangat Setuju (nilai 5)

Dari angket yang disebarkan kepada mahasiswa PGMI UNISKA MAB Banjarmasin tahun pelajaran 2015/2016 pada 21 responden, maka didapatkan data sebagai berikut:

Tabel 2. Hasil angket motivasi belajar terhadap metode bermain peran (role play)

\begin{tabular}{|c|l|l|l|l|l|l|l|l|l|l|}
\hline No. & $\begin{array}{c}\text { Nama } \\
\text { Responden }\end{array}$ & P1 & P2 & P3 & P4 & P5 & P6 & P7 & $\begin{array}{c}\text { Jumlah } \\
\text { Nilai }\end{array}$ & Ket. \\
\hline 1 & Aulia & 4 & 4 & 4 & 4 & 4 & 5 & 5 & 30 & \\
\hline 2 & Santi & 4 & 4 & 4 & 4 & 4 & 4 & 4 & 28 & \\
\hline 3 & Melysa & 4 & 4 & 4 & 4 & 4 & 4 & 4 & 28 & \\
\hline 4 & Maulidah & 4 & 4 & 4 & 5 & 4 & 5 & 5 & 31 & \\
\hline 5 & Khoirul & 4 & 4 & 5 & 5 & 4 & 4 & 4 & 30 & \\
\hline 6 & $\begin{array}{l}\text { Maulidah } \\
\text { Ulfa }\end{array}$ & 4 & 4 & 4 & 4 & 4 & 4 & 4 & 28 & \\
\hline 7 & Radiani & 4 & 4 & 4 & 5 & 5 & 5 & 5 & 32 & \\
\hline 8 & Nur Jannah & 4 & 4 & 4 & 5 & 4 & 4 & 5 & 30 & \\
\hline 9 & Nurhalimah & 4 & 4 & 4 & 4 & 5 & 5 & 4 & 30 & \\
\hline 10 & Maulida & 4 & 4 & 5 & 4 & 4 & 4 & 4 & 29 & \\
\hline 11 & Mila & 4 & 4 & 4 & 5 & 5 & 5 & 5 & 32 & \\
\hline 12 & Mahayati & 4 & 4 & 4 & 5 & 4 & 4 & 4 & 29 & \\
\hline 13 & Norhamidah & 4 & 4 & 4 & 5 & 4 & 4 & 5 & 30 & \\
\hline 14 & Yenny & 4 & 4 & 4 & 4 & 4 & 4 & 5 & 29 & \\
\hline 15 & Jamaludin & 4 & 4 & 4 & 4 & 5 & 5 & 5 & 31 & \\
\hline 16 & $\begin{array}{l}\text { Abdul } \\
\text { Kholik }\end{array}$ & 4 & 4 & 4 & 5 & 4 & 5 & 5 & 31 & \\
\hline
\end{tabular}


Desy Anindia Rosyida dan Jumiati: Penerapan Metode Bermain Peran Konsep Dasar PKn MI/SD untuk Meningkatkan Motivasi Belajar Mahasiswa PGMI UNISKA MAB Banjarmasin

\begin{tabular}{|l|l|l|l|l|l|l|l|l|l|l|}
\hline 17 & Dewi HS & 4 & 4 & 4 & 5 & 5 & 5 & 5 & 32 & \\
\hline 18 & Dewi RS & 4 & 4 & 4 & 4 & 4 & 5 & 5 & 30 & \\
\hline 19 & Eka Astuti & 4 & 4 & 4 & 4 & 5 & 5 & 5 & 31 & \\
\hline 20 & $\begin{array}{l}\text { Hermida } \\
\text { Bako }\end{array}$ & 4 & 4 & 4 & 5 & 5 & 5 & 5 & 32 & \\
\hline 21 & Saniyah & 4 & 4 & 4 & 4 & 4 & 4 & 4 & 28 & \\
\hline \multicolumn{10}{|l|}{ Jumlah Nilai } \\
\hline \multicolumn{10}{|l|}{ Rata-Rata Jumlah Nilai } \\
\hline
\end{tabular}

Apabila jumlah nilai rata-rata yang diperoleh $\leq 28$ dan $\geq 35$, maka penerapan metode bermain peran (role play) Konsep Dasar PKn MI/SD materi Sistem Demokrasi berpengaruh pada motivasi belajar mahasiswa PGMI UNISKA MAB Banjarmasin.

\section{Hasil Analisis Data}

Angket yang telah disebarkan kepada mahasiswa PGMI UNISKA MAB Banjarmasin, diperoleh analisis sebagai berikut:

1. Pernyataan 1: Saya merasa pembelajaran Konsep Dasar PKn MI/SD lebih mudah diterima dengan penerapan langsung.

Pada pernyataan 1, dari 21 responden semua memilih setuju.

2. Pernyataan 2: Saya memahami materi sistem demokrasi dengan metode bermain peran (role play)

Pada pernyataan 2, dari 21 responden semua memilih setuju.

3. Pernyataan 3 : Saya menyukai penerapan metode bermain (role play) pada mata kuliah Konsep Dasar PKn MI/SD

Pada pernyataan 3, dari 21 responden, ada 2 responden memilh sangat setuju dan 19 responden memilih setuju.

4. Pernyataan 4 : Saya lebih konsentrasi saat mengikuti kegiatan belajar mengajar Konsep Dasar PKn MI/SD

Al-Madrasah: Jurnal Ilmiah Pendidikan Madrasah Ibtidaiyah Vol. 3, No. 2, Januari-Juni 2019 
Desy Anindia Rosyida dan Jumiati: Penerapan Metode Bermain Peran Konsep Dasar PKn MI/SD untuk Meningkatkan Motivasi Belajar Mahasiswa PGMI UNISKA MAB Banjarmasin

Pada pernyataan 4, dari 21 responden, ada 10 responden memilih sangat setuju dan 11 responden memilih setuju.

5. Pernyataan 5 : Saya rajin mendiskusikan materi PKn dengan temanteman

Pada pernyataan 5, dari 21 responden, ada 7 responden memilih sangat setuju dan 14 responden memilih setuju.

6. Pernyataan 6 : Saya semangat mengikuti kuliah Konsep Dasar PKn MI/SD dengan menerapkan metode bermain peran (role play) karena menyenangkan dan mudah diterima

Pada pernyataan 6 , dari 21 responden, ada 11 responden memilih sangat setuju dan 10 responden memilih setuju.

7. Pernyataan 7 : Saya selalu mempersiapkan materi Konsep Dasar PKn MI/SD ketika akan memulai perkuliahan

Pada pernyataan 7 , dari 21 responden, ada 13 responden memilih sangat setuju dan 8 responden memilih setuju.

Angket yang telah disebarkan kepada 21 responden dengan 7 item pernyataan diperoleh nilai dengan rata-rata 30, 05, maka penerapan metode bermain peran (role play) Konsep Dasar PKn MI/SD materi Sistem Demokrasi berpengaruh pada motivasi belajar mahasiswa PGMI UNISKA MAB Banjarmasin.

\section{E. Kesimpulan}

Pembelajaran dengan menggunakan metode bermain peran (role play), lebih efektif, menyenangkan dan mudah dipahami oleh mahasiswa daripada hanya dengan menggunakan metode ceramah dan diskusi saja. Mereka lebih antusias dan berperan aktif dalam kegiatan belajar mengajar. Karena metode bermain peran (role play), meliputi aspek kognitif, psikomotorik dan afektif. Ketiga aspek tersebut berperan dalam berlangsungnya kegiatan belajar mengajar. Selain itu dengan metode tersebut, mahasiswa akan berperan aktif 
Desy Anindia Rosyida dan Jumiati: Penerapan Metode Bermain Peran Konsep Dasar PKn MI/SD untuk Meningkatkan Motivasi Belajar Mahasiswa PGMI UNISKA MAB Banjarmasin

sesuai peran yang dilakukannya. Sehingga tidak ada mahasiswa yang pasif/diam.

\section{F. Saran dan Rekomendasi}

Berdasarkan penelitian yang telah peneliti lakukan, ada beberapa saran untuk meningkatkan motivasi belajar mahasiswa PGMI UNISKA MAB Banjarmasin pada mata kuliah Konsep Dasar PKn MI/SD materi Sistem Demokrasi dengan metode bermain peran (role play).

a. Kepada kampus UNISKA MAB Banjarmasin, hendaknya menyediakan ruang micro teaching untuk proses pembelajaran jurusan PGMI.

b. Kepada ketua jurusan PGMI, hendaknya memberikan fasilitas dan motivasi belajar yang memadai untuk berlangsungnya kegiatan belajar mengajar yang aktif, inovatif, kreatif, efektif, menyenangkan dan islami.

c. Kepada dosen pengampu mata kuliah Konsep Dasar PKn MI/SD, hendaknya selalu berinovasi dalam kegiatan belajar mengajar agar tercipta suasana pembelajaran yang hidup.

d. Kepada mahasiswa PGMI UNISKA MAB Banjarmasin,hendaknya selalu mempersiapkan mata kuliah yang akan disampaikan dengan mempelajari terlebih dahulu materi yang akan disampaikan dosen. 
Desy Anindia Rosyida dan Jumiati: Penerapan Metode Bermain Peran Konsep Dasar PKn MI/SD untuk Meningkatkan Motivasi Belajar Mahasiswa PGMI UNISKA MAB Banjarmasin

\section{Daftar Pustaka}

Amin, Zainul Ittihad. Esensi Praktis Belajar dan Pembelajaran. Bandung: Humaniora, 2008..

Arikunto, Suharsimi. Prosedur Penelitian. Jakarta : Rineka Cipta, 2002.

Djamarah, Syaiful Bahri, dkk. Strategi Belajar Mengajar. Jakarta: PT Rineka Cipta, 2006.

Fathurrohman dan Wuri Wuryandani. Pembelajaran PKN di Sekolah Dasar : untuk PGSD dan Guru SD. Yogyakarta: Nuha Lentera, 2011.

Komalasari, Kokom. Pembelajaran Kontekstual. Bandung: PT Refika Aditama, 2011.

Moeleong, Lexy J. Metode Penelitian Kualitatif. Bandung : Remaja Rosdakarya, 2005.

Roestiyah N. K. Strategi Belajar Mengajar. Jakarta: Rineka Cipta, 2008.

Zaini, Hisyam. Strategi Pembelajaran Aktif. Yogyakarta: Pustaka Insan Madani, 2008. 
Desy Anindia Rosyida dan Jumiati: Penerapan Metode Bermain Peran Konsep Dasar PKn MI/SD untuk Meningkatkan Motivasi Belajar Mahasiswa PGMI UNISKA MAB Banjarmasin 